\title{
Cost and profit conditions in the Hungarian intensive apple production
}

\author{
Apáti, F. ${ }^{1}$, Wang, X. ${ }^{2} \&$ Racskó, J. ${ }^{3}$ \\ ${ }^{I}$ Department of Farm Business Management, Faculty of Agricultural Economics and Rural Development, Centre \\ for Agricultural Sciences, University of Debrecen, 138 Böszörményi St., H-4032 Debrecen Hungary, \\ Email:fapati@agr.unideb.hu \\ ${ }^{2}$ Hugeland Technologies Co., Ltd., Zhongcheng, Room 503 No. 25, Huayuan road, Haidian District, \\ Beijing,P.R.China,Email:wangxichun@hugeland.com \\ ${ }^{3}$ Institute for Research and Development, University of Debrecen, 4032 Debrecen, 138 Boszormenyi, Hungary,
}

Email:racsko@agr.unideb.hu

Summary: In this study I investigated the cost and profit conditions and the efficiency of intensive, qualitative apple production on the basis of a data collection carried out in ventures of high standard production. I concluded that the intensive apple production has an extremely high cost requirement, the production costs are approximately 1500 to 1600 thousand HUF per hectare. In an average case, a production value of 2000 thousand HUF per hectare may be reached, which may fluctuate in a wide interval during the years. Considering the above mentioned, a net profit of 400 to 500 thousand HUF may be realized in one hectare. It should be highlighted that regarding the present marketing conditions, realizing the appropriate profit may be expected only by producing 30 to 40 tons per hectare yields and 80 to $90 \%$ food quality ratio.

Key words: apple plantation, profitability, orchard, economic analysis

\section{Introduction}

Fruit production has an outstanding role in the Hungarian agriculture, which is proved by the fact that it ties down a significant number of labour and assets in billion HUF, and it contributes to the gross production value of crop production by 8 to $10 \%$ (Kiss, 2003). Fruit production has a relevant significance in improving living standard of rural population in lagged behind regions where the conditions of production site is weaker (Papp, 1999). Similarly to other branches of the national economy, our apple production has also been in a deep crisis for a long time. This is well indicated by the continuous, unstoppable yield decrease since the last decade in comparison with 1970 s and 1980 s, when the annual yield reached the 1 million tons. The produced yield of the Hungarian apple reached 450 to 500 thousand tons during the past years, though unfortunately there were years when it did not reach even the 400 thousand tons. In 1995, it hardly exceeded the 300 thousand tons (Gonda, 2000). The shrinkage of the enterprise was demonstrated by the continuous decline of the product quality, and the technical and technological standard of the production, as well as by the depression of the state of the orchard besides the quantity reduction. Besides these negative tendencies, new trends have already appeared for the half decade. Using marketable species even in Europe, establishing up-to-date, intensive orchards and technical and technological development started (Mihályka, 2004). The Hungarian vegetable and fruit enterprises do not even approach to its maximal performance. The level of the yields is low, many products of bad quality get into markets, the technology and genus structure are out of date, and the domestic consumption is extremely low. Considering our future, it can be concluded that the besides the previous mentioned, depressed technical standard, the segmentation of the production, the low level of co-operation, the sufficient storing capacity, and the presently low standard of service background helping in getting to markets are big disadvantages in competition. At the same time, the excellent nutrient content of our products, our comparative advantage in natural conditions and the favourable input-output relations originating from this, are advantages in the sharp competition (Lux, 2005).

Developing orchards and improving the technology, the products and the services are essentially important in increasing the market competitiveness of the apple production for food purposes. The foundation of the increasing market competitiveness cannot neglect the detailed farm business analysis. In connection with these, our aims in this study were the followings. To investigate:

- production costs, cost structure,

- prime cost,

- output, production value,

- profit, profitability. 
Our investigations relate to ventures producing of good standard and having 20 to 30 hectares or more. In this way, our results concern this type.

The "good production standard" may be hardly defined and an extremely relative concept. The production standard is determined by several factors, but primarily the factors of output, such as yields and product quality. Thus during our work, we selected the firms being classified into this group according to professional and experimental way on one hand, and on the basis of the following rule on the other hand: a firm or a plantation is considered to produce on a good standard considering the present expectations if it is able to realize an average yield of 30 tons per hectare for a long run, from which at least $80 \%$ is of food quality.

\section{Materials and methods}

The economic analysis involves the evaluation of the production and post harvest concerning every detail as the two major phases of apple production. The relevant data were collected by the help of technological data collective sheets in producing enterprises.

In case of farm business research, the data collection is a general problem, mainly collecting the necessary information for cost examinations. As it can be strongly supposed that the majority of the ventures do not keep a detailed registration on the costs (counting reports are not clear from the point of view of economic analysis and they distort the reality), this problem was eliminated by the fact that we focused on not the cost but the inputs during our data collection that is on the natural quantity of resources utilized for the sake of the production.

The gained natural data mass could be turned into costs by evaluating the inputs on market prices. The major objective of this method is that the problem of difficulty in collecting data ceases as they can give precise information not on the costs of the farmers but the technology itself in natural values such as the carried out work, the average performance, as well as the utilized materials.

The basis of analyzing and evaluating work of our study in harmony with the previous statements is the farm business model developed on the basis of own data collection.

\section{Results}

We carried out investigations relating to cost and profit conditions of up-to-date intensive plantations during the research. This kind of plantation in Hungary is characterized by 30 to 40 tons per hectare average yield, a food quality ratio exceeding 80 to $90 \%$, and high standard of inputs. The parameters of the analyzed plantation type: M9 weak rootstock, slender spindle-like crown form and 4,0 1,0 meter spatial position, which means 2500 trees per hectare. The present marketable species such as Jonagold, Gala-species and Golden Rainders are among the produced species in a great ratio. Fixing the parameters above mentioned is very important from farm business aspects because we cannot talk about the economics of apple production, and about the costs and profitability of apple production in general, as costs and yield conditions are totally different in an intensive plantation than in a traditionally cultivated orchard.

When analyzing the apple production from the economic aspects, we focus on one production year that is we characterize one year from the period of the whole products. We would like to highlight the fact that the introduced numbers and calculations relate to a normal year free from greater positive or negative climatic and plant protecting extremities. Besides we would like to underline that we suppose a production technology of good standard. In this view, the introduction of the major results from the analysis of production costs, production value and profit conditions come next.

\section{Production cost}

Production costs may be classified according to several aspects depending on the fact that what we want to examine and what questions we look for the answers. Most frequently, in enterprise economy, the production is characterized by operational and cost type cost structure.

The operational cost structure of apple production reflects (Table 1 ) that two thirds of the direct production costs arise during production, while one third in the post

Table 1. Costs of the Hungarian intensive apple production by working phases

\begin{tabular}{|c|c|c|c|}
\hline Phases & $\begin{array}{c}\text { Cost } \\
\text { (thousand } \\
\text { HUF/ha) }\end{array}$ & $\begin{array}{c}\text { Distribution } 1 \\
(\%)\end{array}$ & $\begin{array}{c}\text { Distribution2 } \\
(\%)\end{array}$ \\
\hline "Production" cost & 947 & 66 & 100 \\
\hline From which: Winter pruning & 31 & 2 & 3 \\
\hline Soil cultivation & 13 & 1 & 1 \\
\hline Using manure & 94 & 7 & 10 \\
\hline Plant protection & 305 & 21 & 33 \\
\hline Yield regulation & 31 & 2 & 3 \\
\hline Irrigation & 37 & 3 & 4 \\
\hline Harvesting & 180 & 12 & 19 \\
\hline Other & 1 & 0 & 0 \\
\hline Depreciation of the plantation & 255 & 18 & 27 \\
\hline "Post harvest" cost & 498 & 34 & 100 \\
\hline From which: Storing & 400 & 27 & 80 \\
\hline Preparing for goods & 98 & 7 & 20 \\
\hline DIRECT PRODUCTION COST & 1445 & 100 & \\
\hline
\end{tabular}

Source: own calculation 
harvest period. The last one consisted of the costs of storage for 6 to 8 months.

Data show, that the cost of plant protection excel from the "production" cost, which constitute a one third ratio of the whole cost of the production. Furthermore, significant costs belong to harvesting (20\%) as well as to using manure $(10 \%)$.

Though the depreciation of the plantation cannot be considered as a working phase in a strong meaning, as it is the value of the investment cost projected to one year of the operation, but for the sake of completeness it should be mentioned here. Its ratio within the production cost cannot be neglected as by its one quarter ratio it is the second most significance cost.

After the operational cost structure of the technology of apple production, we look through the cost type structure (Table 2).

Table 2 reflects the direct production cost of 1445 thousand HUF by cost types which was detailed in phases previously. This was supplemented by the overhead costs for the sake of completeness. Their ratio is between 5 and $15 \%$ within the total production cost depending on the size, the production structure and the management, etc. of the venture. The total cost of apple production is 1500 to 1600 thousand HUF per hectare.

The most significant cost of apple production is material cost by a ratio of near $40 \%$. This is followed by the depreciation cost constituting one quarter of the production cost. Machinery cost and labour cost represent a near equal ratio within the production cost by $20 \%$. We did not calculate the other direct costs (e.g. insurance fee, land rent fee), because they are not typical costs, but if they arise, they can further increase the cost of production by 100 to 150 thousand HUF.

15 to $20 \%$ of the storage cost is material cost (energy, fixture), its 70 to $80 \%$ is depreciation cost (building, machine, wrapping) and only 3 to $5 \%$ belong to labour and other costs. The cost structure of preparing for goods depends heavily on the method and technology (manual, machine-made) of sorting and on the method of wrapping, thus a definite cost structure cannot be determined.

Summarizing the production cost subject, it can be concluded that apple production is rather a cost requiring activity. Its cost per hectare may reach the 1600 thousand HUF in case of 30 to 40 tons per hectare.

\section{Production value}

Table 3 reflects production value calculation typical to apple production. In a favourable case, the yield of 35 tons per hectare consists of $90 \%$ product of food quality and apple for industrial purposes is produced as by-products. During the previously supposed 6- to 8-month-long storing period (naturally in case of apple for food consumption), at least a storing loss of $5 \%$ should be calculated which involves shrinkage, decay and transformation. This kind of low
Table 2. Costs of the Hungarian intensive apple production by cost types

\begin{tabular}{|c|c|c|}
\hline Denomination & $\begin{array}{c}\text { Cost } \\
\text { (thousand } \\
\text { HUF/ha) }\end{array}$ & $\begin{array}{c}\text { Distribution } \\
(\%)\end{array}$ \\
\hline „Production" cost & 947 & 60 \\
\hline From which: Material cost & 349 & 22 \\
\hline Labour cost & 171 & 11 \\
\hline Machinery cost & 172 & 11 \\
\hline Depreciation of plantation & 255 & 16 \\
\hline Other direct cost & 0 & 0 \\
\hline From which: Storing & 400 & 25 \\
\hline Preparing for goods & 98 & 6 \\
\hline PIREC harvest” cost & 1445 & 91 \\
\hline Overhead cost & 137 & 9 \\
\hline TOTAL PRODUCTION COST & $\mathbf{1 5 8 2}$ & 100 \\
\hline
\end{tabular}

Source: own calculation

Table 3. Production value in the Hungarian intensive apple production

\begin{tabular}{|c|c|c|}
\hline Denomination & Unit & Value \\
\hline Total yield & t/ha & 35,0 \\
\hline $\begin{array}{l}\text { From which: apple for food } \\
\text { apple for industrial } \\
\text { purposes }\end{array}$ & t/ha & 31,5 \\
\hline Storing loss $(5 \%)$ & t/ha & 1,6 \\
\hline Marketing priceapple for food & $\mathrm{HUF} / \mathrm{kg}$ & 65,0 \\
\hline $\begin{array}{l}\text { apple for industrial } \\
\text { purposes }\end{array}$ & $\mathrm{HUF} / \mathrm{kg}$ & 15,0 \\
\hline thousand HUF/ha & 1997,5 & \\
\hline From which: apple for food & thousand HUF/ha & 1945,0 \\
\hline $\begin{array}{l}\text { apple for industrial } \\
\text { purposes }\end{array}$ & thousand HUF/ha & 52,5 \\
\hline thousand HUF/ha & 18,0 & \\
\hline Agricultural-environmental subsidy & thousand HUF/ha & 0,0 \\
\hline PRODUCTION VALUE & thousand HUF/ha & 2015,5 \\
\hline
\end{tabular}

Source: own calculation

storing loss may be reached only in ULO-containers. It can be even $10 \%$ in traditional containers. The ratio of the loss naturally depends on the period of storing, and greater and greater loss may be expected as time goes by.

When determining production value during planning work, the most difficult task is the selection of prices, considering the fact that prices may fluctuate within a wide interval. The price of apple for food consumption is between 40 and 120 HUF per kilogram, which is determined mainly by species, size, quality and the time of marketing. Regarding this last one, the prices of the summer and fall apple is favourable until the middle of September, when the apple can be sold by 60 to 80 HUF per kilogram but after then the market collapses as directly after picking winter 
apple swamps the market which should be sold without storing, and the price decreases to 40 to 50 HUF per kilogram. Smartening can be realized from January (when apple has already been sold from cellars and temporary containers), and the price continuously rises until the end of the season (May-July) and it can reach even 100 to 120 HUF per kilogram. The aim of permanent storing is to expand the time of marketing to this period. One should not forget that it has a price, too, as the surplus revenue due to the higher prices in comparison with fall marketing is only one side; the other is the revenue lack because of storing costs and storing losses.

Regarding every factor, revenue of 2 million HUF per hectare may be reached in apple production. It may be easily calculated that what happens if the price is only 40 HUF per kilogram, or if it is 120 HUF per kilogram. That is it is clear that the price can fluctuate in an extremely wide interval. The ratio of apple for industrial purposes is minimal, only 2 to $3 \%$, which is thanked to the high ratio of products of food quality (Table 3).

In Hungary, basically there are two direct payments in apple production, which can be calculated. The value of SAPS is rather low (18 thousand HUF per hectare), while agricultural-environmental subsidy for the method of environmental friendly production is near 100 thousand HUF per hectare, which cannot be neglected from the production value, however, it was not taken into consideration.

Aggregating revenue and subsidies, a production value of 2 million HUF may be reached, which is considered as an average value for ventures producing on good standard. It is essential, however, that this value shows a fluctuation of even 200 to $300 \%$.

\section{Profit, profitability}

The basically objective of farming is to maximize profit; in this way the most important factor is the reachable profit. The profit from farm business aspects is the difference between production value and production cost. In counting meaning, it equals with the business performance profit. As focusing on enterprise economy, we do not calculate either results of financial operations or exceptional results because these are determined not at the enterprise level, but at the level of venture. For the same reason, we neglect the obligation to pay income tax.

Table 4. Profit in the Hungarian Apple Production

\begin{tabular}{|l|l|r|}
\hline \multicolumn{1}{|c|}{ Denomination } & \multicolumn{1}{c|}{ Unit } & Value \\
\hline PRODUCTION VALUE & Thousand HUF /ha & 2015,5 \\
\hline Direct production cost & Thousand HUF /ha & 1445,0 \\
\hline CONTRIBUTION & Thousand HUF /ha & 570,5 \\
\hline Overhead cost & Thousand HUF /ha & 137,0 \\
\hline Total production cost & Thousand HUF /ha & 1582,0 \\
\hline NET PROFIT & Thousand HUF/ha & 433,5 \\
\hline
\end{tabular}

Source: Own calculation
We calculate profit by using the already introduced data of production value and production cost in Table 4.

Summarizing the already introduced data of apple production, it can be concluded that a contribution of 570 thousand HUF per hectare may be reached in intensive apple production in ventures producing on good standard and in case of an average year (Table 4). After calculating overhead cost, a net profit of even 400 to 500 thousand HUF may be realized. If the tendencies of marketing prices and yields are favourable, the contribution may exceed the 1 million HUF. Though it may occur, that due to the low prices and even low yields the contribution is negative, but under normal farming conditions, the above mentioned average conditions prevail.

\section{Conclusions}

The intensive apple production is rather a cost demanding activity. The production costs are near 1500 to 1600 thousand HUF. The cost of production takes up of two thirds from this, while the ratio of post harvest is one third. During the production phase, costs of plant protection $(30-35 \%)$, harvesting (near 20\%) as well as of using manure are significant. When examining cost types, the most significant cost is material cost by a $40 \%$ ratio, which is followed by the depreciation constituting one quarter of the costs. Aggregating the revenue and subsidies, a production value of 2000 thousand HUF per hectare is realized, which is regarded as an average value for ventures producing on good standard, but which may fluctuate within a wide interval during the years. Considering the above mentioned, a net profit of 400 to 500 thousand HUF per hectare may be reached. It should be highlighted that an appropriate profit may be realized only by producing yields of 30 to 40 tons per hectare and in case of a food ratio of 80 to $90 \%$.

\section{References}

Gonda, I. (2000): Minôségi almatermesztés. In: Az almatermesztés nemzetközi és hazai helyzete 2000. Szerk. GONDA I. Nyíregyháza. Primom, 13-14.

Lux, R. (2005): A kertészet fejlesztési lehetôségei Stratégiai munkaanyag, Fruitveb Magyar Zöldség-Gyümöles Szakmaközi Szervezet Budapest, 2005.

Mihályka, L. (2004): Miért szorulunk almabehozatalra? Kertészet és Szólészet. 2004/4. 14.

Papp, J. (1999): Az EU-összehasonlításban versenyképes kertészeti ágazatok fejlesztési koncepciójának alapjai. In.: Versenyképes kertészeti ágazatok fejlesztési koncepciójának alapjai - Stratégiai kutatások a Magyar Tudományos akadémián. (Szerk.: Papp, J.) Agroinform Kiadó. Budapest, 1999. 8-14. p.

Z. Kiss, L. (2003): A gyümölcstermesztés feltételrendszere. In.: A gyümölcstermesztés, -tárolás, -értékesítés szervezése és ökonómiája. (Szerk.: Z. Kiss). Mezốgazda Kiadó. Budapest, 2003. 13. p. 